\title{
As representações do meio ambiente de Antonina (PR) como reflexão para a educação ambiental
}

\author{
André Vagner Peron de MORAIS
}

Dissertação de Mestrado: Curso de Mestrado em Geografia - UFPR

Data da defesa: 27 mar. 2003

Banca:

Salete Kozel Teixeira (orientadora)

Francisco de Assis Mendonça

Oswaldo Bueno Amorin Filho

\section{RESUMO}

As transformações legais que ocorreram na educação nas duas últimas décadas, com exceção de algumas iniciativas, não proporcionaram mudanças na metodologia mecanicista de ensino. Nesse sentido, muitos trabalhos apontam que as mudanças cabíveis ao planejamento escolar consistem em fazer da interdisciplinaridade um meio para o processo de ensino-aprendizagem. Nesse contexto, com uma atenção especial para o Ensino Médio, esta pesquisa, ao buscar um norte interdisciplinar quanto à abordagem da Educação Ambiental na escola, trabalhou com representações gráficas do meio ambiente, buscando estabelecer uma relação do conteúdo aprendido com o método tradicional do ensino vigente. No quadro atual, a escola trabalha a problemática ambiental de maneira estanque e pobre, não levando os alunos a construir seus valores subjetivos pautados também nessa relevante questão. Exercitar essa representação de meio ambiente, isto é, torná-la mais elaborada, mais consciente, torna-se um modo de qualificar a própria relação do sujeito da representação com o seu mundo. Numa perspectiva fenomenológica de estudo, buscamos ressaltar como o lugar pode ser o início de um processo pelo qual o aluno compreenda o que está em torno de si, o mundo em diversas escalas. As representações efetivadas em Antonina - PR demonstraram uma significante inquietação dos alunos do Ensino Médio com as condições socioambientais do município. Entretanto, também apresentaram uma Educação Ambiental estanque em relação com o mundo vivido. No intuito de dinamizar e dar uma nova perspectiva ao processo, destacamos algumas possibilidades pedagógicas para esse ensino.

Palavras-chave:

Meio ambiente, educação ambiental. 